\title{
Øst-Timors tilbageslag
}

Sven Gunnar Simonsen

\section{1999 fremstod $\varnothing$ st-Timor som det perfekte la- boratorium for statsbygning under international ledelse. Men siden er meget gået galt}

\section{I februar i år ble Øst-Timor i noen dager synlig på internasjonale medias radar, i og med attentatfor- søkene mot president José Ramos- Horta og statsminister Xanana Gusmão. Nobelprisvinneren Ramos- Horta ble alvorlig såret, mens den tidligere geriljalederen og presi- denten Gusmão unnslapp.}

Forrige gang $\emptyset_{\text {st-Timor var i søke- }}$ lyset var for to år siden, da en konflikt innad i hæren utviklet seg til en krise hvor minst 37 ble drept og 155.000 av landets 1,2 millioner innbyggere flyktet fra sine hjem. Dette skjedde bare et par uker etter at daværende sjef for Verdensbanken, Paul Wolfowitz, besøkte $\emptyset$ st-Timor og gratulerte landets ledere med å ha lykkes i å sikre fred og stabilitet. Også FNs framdriftsplan tilsa at suksessen var sikret: de aller fleste punktene på 'oppdrag utført'-listen var krysset av, og det gjensto bare en måned til den siste, beskjedne FNoperasjonen formelt skulle avsluttes. Øst-Timor var portugisisk koloni i mer enn 400 år. Da det autoritære Salazar-Caetano regimet i Lisboa falt i 1974, løsnet også grepet om koloniene. I Øst-Timor ble friheten fulgt av væpnet strid mellom rivaliserende politiske grupper, noen av dem med støtte fra naboen Indonesia. I desember 1975 invaderte så Indonesia $\emptyset_{\text {st-Timor. Anslagene for }}$ hva okkupasjonen kostet varierer; minst 100.000 men kanskje så mange som 200.000 ble drept eller døde av sult og sykdom forårsaket av okkupasjonen. Motstandsbevegelsen ble likevel aldri helt nedkjempet, og internasjonalt hadde timoreserne mange støttespillere.

Først med den indonesiske diktatoren Suhartos avgang i 1998 fikk timoreserne en ny sjanse. En folkeavstemning om Øst-Timors framtid, administrert av FN, ble avholdt i august 1999. Tross en atmosfære av frykt stemte så mange som 78 prosent for selvstendighet. Indonesias militære trakk seg ut i ukene som fulgte, men lot først sine timoresiske 
militiaer gå berserk. Anslagsvis to tusen mennesker ble drept, to tredeler av befolkningen ble drevet på flukt, og 70 prosent av bygningsmassen ble brent ned.

Noen uker senere vendte FN tilbake, og en massiv internasjonal operasjon ble satt i verk. En FN-administrasjon (UNTAET) regjerte $\emptyset_{\text {st- }}$ Timor fra 1999 til landet ble selvstendig i 2002. 'Alt' hastet da FN ankom Øst-Timor. Å bygge en østtimoresisk stat var en overveldende oppgave. Dette var allerede Asias fattigste land, med størstedelen av befolkningen sysselsatt i naturalhusholdning, og en fødselsrate på åtte barn per kvinne (den høyeste i verden). Og nå altså enorme ødeleggelser og nye traumer i kjølvannet av den indonesiske tilbaketrekningen.

Samtidig var det flere ting som ga grunn til optimisme. Okkupasjonsmakten hadde trukket seg ut, og en samlende nasjonalfølelse hadde vokst fram rundt ønsket om selvstendighet. Internasjonal bistand ble ønsket velkommen, og landet hadde til og med uutnyttede olje- og gassressurser som kunne gi gode inntekter. Med et lite territorium og en liten befolkning virket det hele håndterbart.

\section{Nær nedsmeltning}

\section{2006 kom landet likevel nær en} full nedsmelting. Krisen ble utløst da en gruppe på 600 soldater ble sparket på grunn av tjenesteforsøm- melse. Denne gruppen ble kalt 'petisjonistene' fordi mange av dem hadde undertegnet en petisjon stilet til landets ledere hvor de hevdet at de ble diskriminert fordi de kom fra $\emptyset$ st-Timors vestlige del. Protestene som fulgte utartet til voldelige sammenstøt, først og fremst i hovedstaden Dili. Flere politifolk sluttet seg til petisjonistene. Soldater, politi, petisjonister og væpnede sivile støtte sammen, hærens hovedkvarter og hærsjefens privatbolig ble angrepet, og hæren svarte med å angripe politihovedkvarteret i Dili. I lovløsheten som rådde fikk hovedstadens stadig sterkere ungdomsgjenger herje fritt. Seks tusen hus ble helt eller delvis ødelagt i Dili alene.

I juni gikk Fretilins statsminister Mari Alkatiri motvillig av, og José Ramos-Horta (som hadde gått av som utenriksminister én dag tidligere) tok over. Samme måned kom en australsk-dominert internasjonal militærstyrke til landet, og uroen ble gradvis dempet. I august ble et nytt, stort FN-oppdrag (UNMIT) etablert. Lokale og internasjonale krefter startet gjenoppbyggingen, av bygninger, institusjoner - og tillit.

Øst-Timor sto igjen som et mer splittet samfunn etter krisen. Mest iøynefallende var måten et tidligere ganske uvesentlig regionalt skille mellom folk fra vest (loromonu) og øst (lorosae) i landet - var blitt langt viktigere, og nå preget mange andre konfliktlinjer. Politikk i Øst-Timor hadde lenge vært uforsonlig, men 
ved president- og parlamentsvalgene våren 2007 trådte dette øst-vest-skillet fram på en helt ny måte. Da regjeringspartiet Fretilin mistet makten til en koalisjon ledet av hovedmotstanderen, tidligere president Xanana Gusmão, brøt det ut ny uro i hovedstaden og øst i landet.

Problemet med petisjonistene forble uløst etter 2006-krisen. Flere hundre av dem krevde fortsatt å bli tatt opp igjen i hæren. I løpet av 2007 ble petisjonistene tettere organisert under den tidligere sjefen for militærpolitiet, Alfredo Reinado. Avhopperen Reinado var kjent for sin karisma, men også for sitt store ego. Han var ettersøkt for drap etter 2006-krisen, men var like fullt blitt en helt for enkelte vest i landet.

Statsminister Gusmão på sin side viste stadig større utålmodighet med Reinado, og Reinado må ha ant at hans tid på rømmen snart var ute. I desperasjon - og kanskje stormannsgalskap - slo han til mot landets ledere 11. februar. Reinado ble selv drept i attentatfors $ø$ ket mot president Ramos-Horta.

Med Reinado mistet petisjonistene sin viktigste leder. I ukene som fulgte overga de tidligere soldatene som deltok i attentatforsøkene seg. Reinados høyre hånd, Gastão Salsinha, meldte seg omsider i slutten av april, etter langvarige forhandlinger. Nå arbeider myndighetene med en løsning for de flere hundre petisjonistene som ikke hadde noen rolle $\mathrm{i}$ attentatforsøkene, som har meldt seg for myndighetene og er samlet i en leir i Dili.

Fremdeles må timoreserne leve med unntakstilstanden innført etter 11. februar. Fremdeles er ungdomsgjengene, med ulik regional tilhørighet, sterke. Og 100.000 bor fremdeles i leire for internt fordrevne. I den uklare sikkerhetssituasjonen står arbeidet med økonomisk gjenoppbygging av landet i stampe. Inntektene fra olje- og gassutvinningen kan dekke statens utgifter, men skaper ikke uten videre arbeid til de mange unge som går ledig.

Det finnes lyspunkter. Etter 11 . februar valgte myndighetene som et krisetiltak å legge hæren og politiet under en felles kommando. Det er en midlertidig løsning, som også bekymrer enkelte. Men mange timoresere ser det som positivt at militære og politi faktisk kan jobbe sammen. Sikkerhetstiltakene har også gjort slutt på de hyppige sammenstøtene mellom steinkastende ungdomsgjenger. Dette gjør også at noen internt fordrevne viser større vilje til å vende hjem. Men troen på enkle formler og raske resultater i 'det perfekte laboratorium' er borte nå. Å skape varig stabilitet og utvikling i Øst-Timor er blitt vanskeligere etter de siste årenes tilbakeslag. Langsiktig internasjonal støtte vil øke timoresernes sjanse til å lykkes.

Sven Gunnar Simonsen er seniorforsker ved Institutt for fredsforskning, Oslo (PRIO) 